\title{
Arc Welding Process Selection through a Quality and Costs
}

\author{
Ashish Thakur ${ }^{*}$, Hagos Gebrelibanos ${ }^{2}$ and Tadesse Gabrey ${ }^{3}$ \\ ${ }^{1,3}$ Solid Mechanics and Design Chair, Ethiopian Institute of Technology, Ethiopia \\ ${ }^{2}$ Product Design and Development-EITM, Sr. Design Engineer, Mesfin Industrial Limited, Mekelle, Ethipoia
}

Received 08 March 2019, Accepted 11 May 2019, Available online 13 May 2019, Vol.9, No.3 (May/June 2019)

\begin{abstract}
This paper presents a methodology to compare three welding processes, namely SAW (submerged arc welding), SMAW (shield metal arc welding) and GMAW (gas metal arc welding) and to select the best one for a given application. Study is the selection of arc welding process for improving quality and welding cost case in MIE and proposes a method for determining the welding process by comparing time, quality and cost, against one over the other of the three types of Arc welding. The welds were carried out in MIE training center. The selection was based on double criteria: operational costs and non-quality costs. The former is related to the normal costs evaluated in such kind of decision, like consumable cost, labor cost, etc. The is the financial loss suffered by the client every time response variable drifts away from its target value or presents variability. The results indicated that the non-quality and operational costs for the SAW process are slightly lower in comparison to the GMAW and SMAW. SAW is selective among them for quality wise. Therefore, it is the best process for the given application. However; cost incurs little high for GMAW.
\end{abstract}

Keywords: Arc welding, St-52, quality analysis, cost analysis, process selection

\section{Introduction}

A welding case study is used in this research study. The welds were carried out in radiographic test, mechanical test and microstructure test for the three arc welding processes namely: SMAW SAW with flux shielding, and GMAW with $\mathrm{CO}_{2}$ based shielding gases. For Quality analysis, geometrical aspects of the beads were considered and for cost analysis, welding parameters and consumable prices. Quantitative indices were proposed and evaluated. After that, evaluation of both quality and costs calculated, possible to select the most suitable welding process to a specific application, taking into account the market conditions of a company.

Overhead crane where welding was done is a material handling equipment made of carbon steel St52 is used for lifting, loading, unloading and transportation of semi-finished and finished products mainly in workshops. They are two types namely: (a) single girder and (b) double girder type crane. Solid modeling of assembled overhead crane bridge and overhead crane during welding is shown in Figure 1 and Figure 2 given below.

*Corresponding author's ORCID ID: 0000-0001-9287-700X DOI: https://doi.org/10.14741/ijcet/v.9.3.6

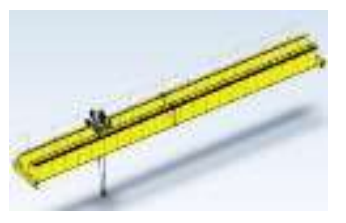

Fig.1.Solid modeling of Overhead Crane Bridge

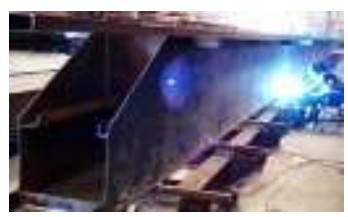

Fig.2.Overhead crane during welding

\subsection{Motivation}

The main concern of dealing with Arc welding was because of continuous internal customers' claim in the company, lot of welding electrodes wastage, low quality product, unnecessary welding cost and unexpected additional consumable material request.

\subsection{Problem statement}

Currently, Mesfin Industrial Engineering (MIE) has been engaged in manufacturing of steel overhead crane bridge structure of different workshops of steel 
manufacturers and dam projects, such as MIE new shops, Ethiopian water construction works, Zarema mayday dam, Ribb dam, Kalema dam manufacture, supply and erection. However, the assembling of the structure is mainly done using three different welding processes(GMAW, SMAW and SAW) that incurred high cost elements like: consumable material cost (electrode, flux and shielding gas), labor cost and electric power cost when compared with estimated design cost. Therefore, the existing steel bridge welding process can be proposed by one welding process effectively and economically without compromising the strength and quality of the product.

\subsection{Objective}

The general objective of this work is to propose, apply and evaluate a methodical approach to select welding processes of overhead crane bridges, based on cost elements and market requirements of Quality and Cost.

\subsection{Significance of the research}

The key significance of the research is to reduce manufacturing cost, increase customer satisfaction, sustaining an affordable product and make the company more productive and profitable.

\section{Literature review}

The research on welding technology optimization of different types of welding for obtaining various responses in output have been done by a number of researchers using a wide range of materials. They make use of various types of methods, techniques and mathematical models for evaluating and obtaining results.

In this research the welding voltage, current, wire speed and gas flow rate are considered as input parameter. The experiment was designed by face centered composite design matrix. From the experiment they conclude that the optimum values of process parameter such as welding voltage $22.5 \mathrm{~V}$, wire speed $2.4 \mathrm{~m} / \mathrm{min}$ and gas flow rate $12 \mathrm{l} / \mathrm{min}$ for maximum yield strength both transverse and longitudinal are remain same but the current value is $190 \mathrm{~A}$ and 210 A respectively(Ajit. H. et al, 2012).

(Patel C. N. et al, 2013) Evaluated the parameters; welding current, wire diameter and wire feed rate to investigate their influence on weld bead hardness for MIG welding and TIG welding by Taguchi's method and Grey Relational Analysis (GRA). From the study it was concluded that the welding current was most significant parameter for MIG and TIG welding. By use of GRA optimization technique the optimal parameter combination was found to be welding current, 100 Amp; wire diameter $1.2 \mathrm{~mm}$ and wire feed rate, 3 $\mathrm{m} / \mathrm{min}$ for MIG welding.
(Lakshminarayanan A.K. et al, 2009) Investigated the AA6061 Aluminum alloy joints mechanical properties welded by gas metal arc welding, gas tungsten arc welding and friction stir welding. Single V joint configuration, pure argon shielding gas and AA4043 filler wire were used for the gas metal arc welding and gas tungsten arc welding. Non consumable high carbon steel tool was used for the friction stir welding. Diamond compound was used for a final polishing. The friction stir weld joints produced the high strength values than GMAW and GTAW. The strength value $34 \%$ higher than the GMAW and $15 \%$ higher than the GTAW. The base metal and heat affected zone produced the high hardness values than the weld metal. FSW produced the high hardness value and GMAW produced low hardness value. Equiaxed uniformly distributed fine grains increased the high tensile properties in the weld region for FSW joints.

It is essential to know the cost of a weld to make manufacturing decisions. An understanding of welding economics / costs and the value added by technology allow a company to manage them and become more profitable. Total welding costs incurred should include: time spent preparing a joint, blasting, removing oils, assembly, preheating, tack-up, positioning, welding, slag removal, spatter removal, inspection, changing electrodes, transportation times, machine setup times, repair and rework. Material costs include: electrodes, shielding gas / gas mixtures, electric power, and gas for preheating (Chaudhuri S. et al).

There is no mystery in Welding-cost estimate: it is mainly a question of common sense. But it must be appreciated that correct accounting for total Weldingcost incurred in a welding operation is a preliminary requirement to the assessment of the best practices and a necessary tool for the economic management of any welding enterprise (Kumar S. et al, 2011).

A good cost estimation model has a direct bearing on the selection of material and the type of manufacturing process. A good cost model also has to deal with the problems of overestimation and underestimation. The break-down cost method requires detailed information about the production process to derive the relevant cost components. Labor, overhead, tooling, maintenance and repair, etc., are the commonly used cost components for developing cost models for any manufacturing process (Tipaji P.K. et al, 2007).

(Tewari S. P. et al, 2010) Analyzed the effect of various welding parameters on the weldability of Mild Steel specimens under the effect of heat input welding current, voltage and speed of wire etc. The welding current, arc voltage, welding speed, heat input rate are chosen as welding parameters. The depth of penetrations were measured for each specimen after the welding operation on closed butt joint and the effects of welding speed and heat input rate parameters on depth of penetration were investigated.

Author investigates the effects of welding process parameters of Gas Metal Arc Welding (GMAW) on 
tensile strengths of SS $3 \mathrm{Cr} 12$ steel material specimen. In this research work, the welding voltage, wire feed rate, welding speed and gas flow rate were considered as inflating input parameter. Medium-carbon steels (below $0.25-0.55 \%$ carbon) are often heat-treated (quenched and tempered) to achieve yet higher strength, but it is mainly the compositions below $0.35 \%$ carbon that are relevant to this report. Carbon steel is one of the most widely used materials in the industry. This material is used not only in many of the water and steam-pressure containing systems in power plants but also in the supports for these systems. Although this report concentrates primarily on the pressure containing applications of carbon steels, it can also be a useful tool for structural carbon steel fabrication issues. As the description implies, the primary alloying element of these iron based materials is carbon. Because carbon is such a powerful alloying element in steel, there are significant differences in the strength, hardness, and ductility achievable with relatively small variations in the levels of carbon in the composition. However, other important factors such as material fabrication, heat treatment, component fabrication, and fabrication processes can result in significant changes to the properties of the carbon steel components. In some cases, requirements established by codes and standards must be supplemented to achieve results when working with carbon steels. It is important for the utility engineer to have access to metallurgical and properties information to aid in making decisions for projects involving carbon steels. Carbon steel is available in virtually all product forms, including both the forms needed for pressure containing applications and the shapes needed for structural applications (Pradip D. Chaudhari et al, 2014; Gupta J.K. et al, 2005).

The applied tensile load and extension are recorded during the test for the calculation of stress and strain. Each standard may contain a variety of test standards suitable for different materials dimensions and fabrication history. When a specimen was subjected to an external tensile loading, the metal would undergo elastic and plastic deformation (AWS et al, 2007; AWS D1.1 et al, 2008; ASTM et al).

This test method covers a guided bend test for the determination of soundness and ductility of welds in ferrous and nonferrous products. Defects, not shown by X-rays, may be appearing the surface of a specimen when it is subjected to progressive localized overstressing. This guided bend test has been developed primarily for plates and is not intended to be substituted for other methods of bend testing (AWS et al, 2007; AWS D1.1 et al, 2008; AWS D1.1 et al, 2008).

\section{Material and Methods}

\subsection{Material}

The specimen materials are prepared from St-52-3, is the engineering material for fabrication of steel crane bridge structures to conduct various tests and analysis required for the project.

\subsection{Methods}

A St-52-3 medium carbon steel plates, with chemical composition and the balance Iron as shown in Table 1 , were selected as base metal for the experiments. The plates were machined into $200 \mathrm{~mm} \times 250 \mathrm{~mm} \times 8 \mathrm{~mm}$ as weld blanks. The surface of the plates were grind and polished to remove the dust and other foreign particles. In order to obtain a strong bonded joint the properties of the base metal and the welding wire must comply with each other. The type of material of welding wire total depends upon the material that is required to be welded. So ER 70S- 6 was selected as MIG welding wire, E7018 for SMAW and AWS A5.17E12 as SAW wire whose chemical composition are as shown in Table 1 . The diameter of the welding wire or electrode depends upon the base metal thickness.

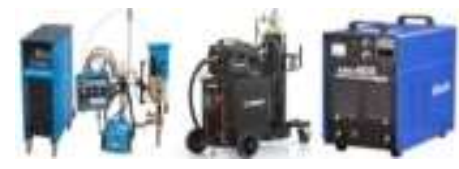

Fig.3. Types of welding machines

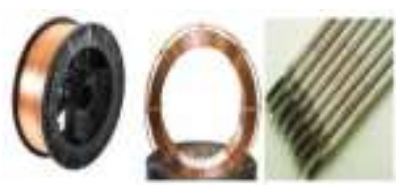

Fig. 4. Types of welding wires/electrodes

Types of welding machines are shown in Figure 3 given above. As the thickness of base metal was $8 \mathrm{~mm}$, welding wire with a diameter of $1.2 \mathrm{~mm}$ for MIG, $4 \mathrm{~mm}$ for SAW and $3.2 \mathrm{~mm}$ for SMAW were selected as given in Figure 4 above.

Table 1: Chemical compositions of welding wires/electrodes

\begin{tabular}{|c|c|c|c|c|c|c|c|c|c|c|}
\hline \multicolumn{11}{|c|}{ Percentage Chemical composition of welding wires/electrodes } \\
\hline $\begin{array}{l}00 \\
0 \\
0 \\
.00 \\
00 \\
3 \\
3\end{array}$ & $u$ & $\sum$ & $\dot{\omega}$ & 2 & $n$ & $\bar{z}$ & $\dot{U}$ & $\sum^{0}$ & $>$ & $\Xi$ \\
\hline 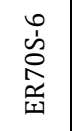 & $\begin{array}{l}n \\
\stackrel{1}{0} \\
0 \\
\dot{1} \\
0 \\
0\end{array}$ & 노 & 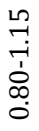 & 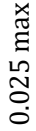 & 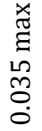 & 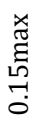 & 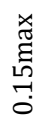 & 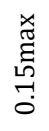 & 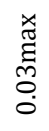 & 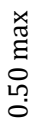 \\
\hline$\stackrel{\infty}{\stackrel{\infty}{2}}$ & 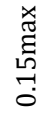 & 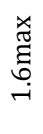 & 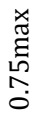 & 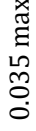 & 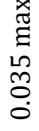 & 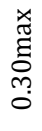 & 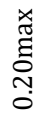 & 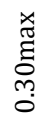 & $\begin{array}{l}\underset{x}{\varpi} \\
\stackrel{\Xi}{0} \\
0 \\
0 \\
0\end{array}$ & ' \\
\hline 党 & $\begin{array}{l}\stackrel{+}{-} \\
\dot{0} \\
\dot{1} \\
\dot{0} \\
0\end{array}$ & $\begin{array}{l}\stackrel{8}{0} \\
\stackrel{1}{0} \\
\stackrel{1}{0}\end{array}$ & 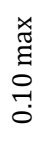 & $\begin{array}{l}\text { x. } \\
\text { है } \\
0 \\
\tilde{m} \\
0 \\
0\end{array}$ & 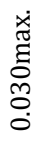 & ' & ' & ' & & 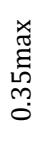 \\
\hline
\end{tabular}




\subsubsection{Chemical composition testing}

MIE's Belec compact port spectrometry machine used for chemical characterization is shown in Figure 5 given below.

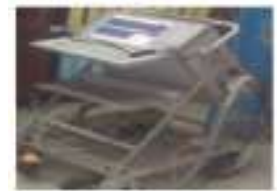

Fig. 5. MIE's Belec compact port spectrometry machine

\subsubsection{Visual Inspection (VI) and Radiographic Testing} (RT)Visual Inspection (VI)

Dimensions of bevels and grooves, and values of misalignment and angular distortion which affect the quality of welds and the performance of joints are inspected visually.

\section{Radiographic Testing (RT)}

This method of weld testing makes use of X-rays, produced by an X-ray tube, or gamma rays, produced by a radioactive isotope. Penetrating radiation is passed through a solid object that is in a weld joint, onto a photographic film, resulting in an image of the object's internal structure being deposited on the film.All discontinuities are detected by viewing shape and variation in density of the processed film. This testing method is usually suited to having access to both sides of the welded joint. Test machine to conduct radiographic and X-ray is shown in Figure 6(a) Radiographic test machine (b) X-Ray viewer machine given below.

\section{Radiographic procedures}

\section{Step 1: Welding the specimens}

Step 2: Visual inspection the welding surface

Step 3: the film is immersed in standard developer and fixer solutions accordance with manufacturer's recommendation washing the film with water to remove all the processing chemicals

Step 4: drying the film to be suited for viewing Step 5: after the film processed, washed and dried, radiographs are viewed by a qualified personnel using $\mathrm{X}$-ray film viewer or a light box with high light intensity machine and interpreted it.

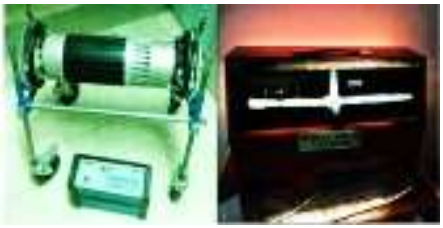

(a)

(b)

Fig. 6. (a) Radiographic test machine (b) X-Ray viewer machine

\subsection{Mechanical testing}

\subsubsection{Tensile testing}

The standard dimension of specimens subjected for tensile strength testing was prepared according to ASTM E8/E8M - 09. It was machined using milling machine to get the required shape and size. The tensile test specimens' specification is shown in Figure 7 given below. The Tensile testing machine used to conduct tensile tests is shown in Figure 8 (a), (b) and (c) given below.

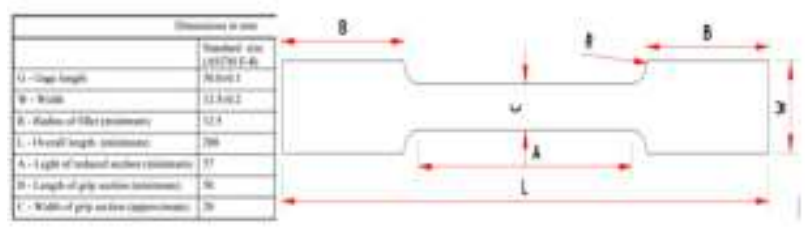

Fig 7.Tensile test specimen specification

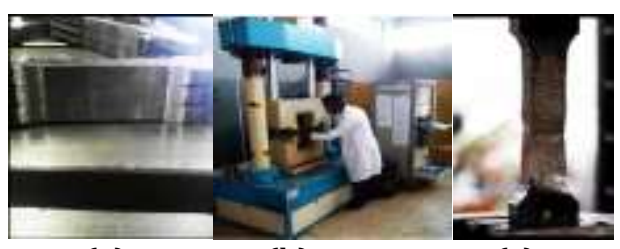

(a)

(b)

(c)

Fig 8. (a) Machined tensile test specimen,(b) Tensile test machine during testing, and (c) Tensile test specimen during testing

\subsubsection{Metallography}

Metallographic samples were produced from welds in accordance to ASTM E3-11(2017).The samples were polished and etched using 2\% Nital solution (Nitric acid and methanol).Optical Microscope attached digital camera used for microstructural observation is shown in Figure 9 given below.

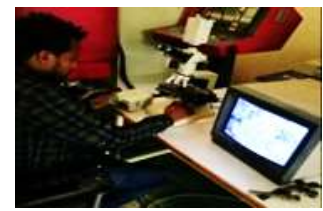

Fig. 9.0ptical microscope attached digital camera used for microstructural observation

\subsection{Analysis of Quality}

In manufacturing industries, the general term quality refers into the two complementary categories of quality of design and quality of conformance. Whereas quality of design focuses on how the product design meets consumer requirements, quality of conformance is concerned with whether the quality produced and provided to the consumer meets the intended design. Improving produced quality of conformance via defect prevention and improving quality of conformance delivered to the customer via inspection. 


\subsection{Cost analysis}

Costs determination can be used for composing sale price, helping take decisions about a product fabrication opportunity, determining the necessary investment volume for an operation, predicting modifications owing to fabrication scale changes, establishing the principles to implement a cutting cost program and providing assistance to a welding process selection. In the present case, costs will be used as a balancing parameter during selection of the most suitable welding process.

\section{Results and Discussion}

\subsection{Results}

\subsubsection{Visual inspection of welding}

During the observation at the welding training shop of Mesfin Industrial Engineering PLC, the defect of the weld St52-3 was seen on some surfaces of weld. All of the welded St52-3 plate was being observed visually. Visual inspections for welded specimen data are presented in Table 2 given below.

Table 2:Visual inspection examined welded joint

\begin{tabular}{|c|c|c|c|c|c|c|c|c|c|}
\hline 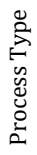 & 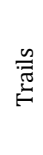 & 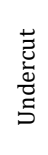 & $\begin{array}{l}\frac{\tilde{\sigma}}{\bar{D}} \\
\text { ठे }\end{array}$ & 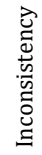 & $\begin{array}{l}\overrightarrow{\widetilde{U}} \\
\overrightarrow{\widetilde{D}} \\
\stackrel{0}{\omega}\end{array}$ & 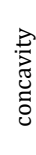 & $\begin{array}{l}\overrightarrow{\mathrm{x}} \\
\text { गे } \\
\overrightarrow{0}\end{array}$ & 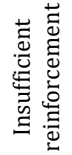 & 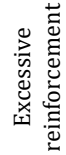 \\
\hline \multirow{5}{*}{ 交 } & $\vec{E}$ & $\overline{\bar{z}}$ & $\overline{\bar{z}}$ & $\bar{z}$ & $\overline{\bar{z}}$ & $\bar{z}$ & $\bar{z}$ & $\bar{z}$ & $\overline{\bar{z}}$ \\
\hline & 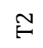 & $\overline{\bar{z}}$ & $\overline{\bar{z}}$ & $\bar{z}$ & $\bar{z}$ & $\bar{z}$ & $\bar{z}$ & $\bar{z}$ & $\bar{z}$ \\
\hline & $\stackrel{m}{H}$ & $>$ & $\overline{\bar{z}}$ & $\bar{z}$ & $\bar{z}$ & $\bar{z}$ & $>$ & $\bar{z}$ & $\overline{\bar{z}}$ \\
\hline & $\stackrel{F}{F}$ & $\bar{z}$ & $>$ & $\bar{z}$ & $>$ & $\bar{z}$ & $\bar{z}$ & $\bar{z}$ & $\bar{z}$ \\
\hline & $\stackrel{\varrho}{\epsilon}$ & $\overline{\bar{z}}$ & $\overline{\bar{z}}$ & $\overline{\bar{z}}$ & $\overline{\bar{z}}$ & $\bar{z}$ & $\overline{\bar{z}}$ & $\bar{z}$ & $\bar{z}$ \\
\hline \multirow{5}{*}{$\sum_{j=1}^{3}$} & $\vec{F}$ & $\overline{\bar{z}}$ & $\overline{\bar{z}}$ & $\bar{z}$ & $>$ & $\bar{z}$ & $\bar{z}$ & $\bar{z}$ & $\bar{z}$ \\
\hline & $\cong$ & $\bar{z}$ & $\bar{z}$ & $\bar{z}$ & $\bar{z}$ & $\bar{z}$ & $\bar{z}$ & $\bar{z}$ & $\bar{z}$ \\
\hline & $\stackrel{m}{\epsilon}$ & $\overline{\bar{z}}$ & $\overline{\bar{z}}$ & $\overline{\bar{z}}$ & $\overline{\bar{z}}$ & $\overline{\bar{z}}$ & $>$ & $\bar{z}$ & $>$ \\
\hline & $\stackrel{\vec{F}}{ }$ & $>$ & $\overline{\bar{z}}$ & $\bar{z}$ & $\bar{z}$ & $>$ & $\bar{z}$ & $\overline{\bar{z}}$ & $\overline{\bar{z}}$ \\
\hline & $\stackrel{\omega}{\mu}$ & $\overline{\bar{z}}$ & $\overline{\bar{z}}$ & $\bar{z}$ & $\overline{\bar{z}}$ & $\overline{\bar{z}}$ & $>$ & $\bar{z}$ & $\bar{z}$ \\
\hline \multirow{5}{*}{$\sum_{i=1}^{3}$} & $\tilde{F}$ & $\bar{z}$ & $\bar{z}$ & $>$ & $>$ & $\overline{\bar{z}}$ & $\overline{\bar{z}}$ & $\overline{\bar{z}}$ & $>$ \\
\hline & 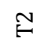 & $\overline{\bar{z}}$ & $\overline{\bar{z}}$ & $\bar{z}$ & $>$ & $\bar{z}$ & $>$ & $\bar{z}$ & $>$ \\
\hline & $\stackrel{m}{\varphi}$ & $\overline{\bar{z}}$ & $>$ & $>$ & $>$ & $\overline{\bar{z}}$ & $>$ & $\overline{\bar{z}}$ & $\overline{\bar{z}}$ \\
\hline & $\mathrm{T} 4$ & Nil & $\sqrt{ }$ & Nil & Nil & Nil & Nil & $\sqrt{ }$ & Nil \\
\hline & T5 & Nil & Nil & Nil & Nil & $\mathrm{Nil}$ & Nil & $\sqrt{ }$ & Nil \\
\hline
\end{tabular}

Where:

Nil -no defects

$\sqrt{ }$... there is defects

From the visual inspection results of Table 2, it comprises that the overall welded specimen parameter of the level that have T3 and T4 in SAW, and T3, T4,and T5 in GMAW, and T1, T2, T3, T4, T5 in SMAW have defects.However, SMAW have more defect in comparison to GMAW and SAW.

\subsubsection{Radiographic inspection of welding}

Welding radiographic inspection reports are presented in Table 3 given below. Overall comparison of radiographic inspection, fewer defects are observed in SAW, GMAW and SMAW.

Table 3: Radiography test results report of the evaluator

\begin{tabular}{|c|c|c|c|c|c|c|}
\hline \multicolumn{7}{|c|}{ Welding radiographic inspection report } \\
\hline 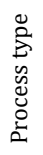 & $\frac{\frac{n}{\pi}}{\underline{n}}$ & $\begin{array}{l}\frac{3}{5} \\
0 \\
0 \\
0\end{array}$ & 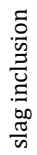 & 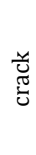 & 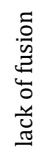 & $\begin{array}{l}\text { 童 } \\
\text { 总 }\end{array}$ \\
\hline \multirow{5}{*}{ 离 } & T1 & $\mathrm{N}$ & $\mathrm{N}$ & $\mathrm{N}$ & $\mathrm{N}$ & $\mathrm{N}$ \\
\hline & T2 & $\mathrm{N}$ & $\mathrm{N}$ & $\mathrm{N}$ & $\mathrm{N}$ & $\mathrm{N}$ \\
\hline & T3 & $\mathrm{N}$ & $\mathrm{N}$ & $\mathrm{N}$ & $\mathrm{N}$ & $\mathrm{N}$ \\
\hline & $\mathrm{T} 4$ & $\mathrm{~N}$ & $\mathrm{Y}$ & $\mathrm{N}$ & $\mathrm{N}$ & $\mathrm{Y}$ \\
\hline & T5 & $\mathrm{N}$ & $\mathrm{N}$ & $\mathrm{N}$ & $\mathrm{N}$ & $\mathrm{N}$ \\
\hline \multirow{5}{*}{ 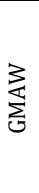 } & T1 & $\mathrm{Y}$ & $\mathrm{N}$ & $\mathrm{N}$ & $\mathrm{Y}$ & $\mathrm{N}$ \\
\hline & T2 & $\mathrm{N}$ & $\mathrm{N}$ & $\mathrm{N}$ & $\mathrm{N}$ & $\mathrm{N}$ \\
\hline & T3 & $\mathrm{N}$ & $\mathrm{N}$ & $\mathrm{N}$ & $\mathrm{N}$ & $\mathrm{N}$ \\
\hline & T4 & $\mathrm{N}$ & $\mathrm{N}$ & $\mathrm{N}$ & $\mathrm{N}$ & $\mathrm{N}$ \\
\hline & $\mathrm{T} 5$ & $\mathrm{~N}$ & $\mathrm{~N}$ & $\mathrm{~N}$ & $\mathrm{~N}$ & $\mathrm{~N}$ \\
\hline \multirow{5}{*}{$\sum_{\infty}^{3}$} & T1 & $\mathrm{N}$ & $\mathrm{N}$ & $\mathrm{N}$ & $\mathrm{N}$ & $\mathrm{N}$ \\
\hline & $\mathrm{T} 2$ & $\mathrm{Y}$ & $\mathrm{Y}$ & $\mathrm{N}$ & $\mathrm{Y}$ & $\mathrm{N}$ \\
\hline & T3 & $\mathrm{N}$ & $\mathrm{N}$ & $\mathrm{N}$ & $\mathrm{N}$ & $Y$ \\
\hline & $\mathrm{T} 4$ & $\mathrm{~N}$ & $\mathrm{~N}$ & $\mathrm{~N}$ & $\mathrm{~N}$ & $\mathrm{~N}$ \\
\hline & T5 & $\mathrm{N}$ & $\mathrm{N}$ & $\mathrm{N}$ & $\mathrm{N}$ & $\mathrm{N}$ \\
\hline
\end{tabular}

Where:

$\mathrm{N}$-no defects

$\mathrm{Y}$... there is defects

\subsubsection{Chemical, Mechanical and Microstructure testing}

4.1.3.1 Chemical composition analysis result of the welded St 52-3 steel

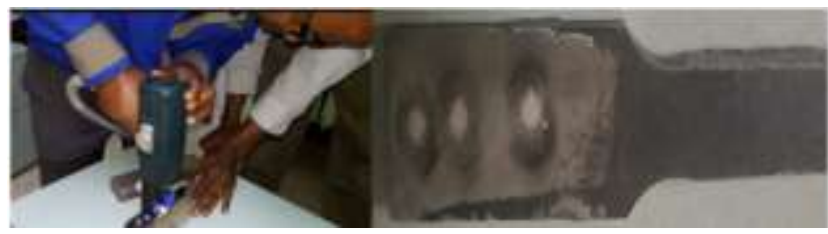

(a)

(b)

Fig. 10. (a) Chemical composition testing, (b) Spot marks after testing 
Chemical composition tests to conduct for chemical composition is shown in Figure 10 (a) Chemical composition testing (b) Spot marks after testing given above. The obtained chemical composition results for the materials are given in the Table 4 below.

Table 4: Summarized value of the material chemical composition result of specimen

\begin{tabular}{|c|c|c|}
\hline No. & Aver. & \\
\hline $\mathrm{C}$ & 0.185 & \\
\hline $\mathrm{Si}$ & 0.039 & \\
\hline Mn. & 1.017 & \\
\hline $\mathrm{Cu}$ & 0.02 & \\
\hline $\mathrm{Al}$ & 0.005 & \\
\hline $\mathrm{Cr}$ & 0.014 & \\
\hline Mo & 0.005 & \\
\hline $\mathrm{Ni}$ & 0.016 & \\
\hline V & 0.042 & \\
\hline $\mathrm{Ti}$ & 0.008 & \\
\hline $\mathrm{Nb}$ & 0.023 & \multirow{3}{*}{$\begin{array}{c}\text { Grade:1.0570, St } \\
52-3\end{array}$} \\
\hline Co & 0.03 & \\
\hline W & 0.111 & \\
\hline
\end{tabular}

\subsubsection{Tensile test}

Tensile tested non-heat treated SMAW; MIG and SAWspecimens wereconducted at Mekelle University shown in Figure 11. Tensile test results of non-heat treated samples for SAW, GMAW and SMAW are shown in Table 5 below.

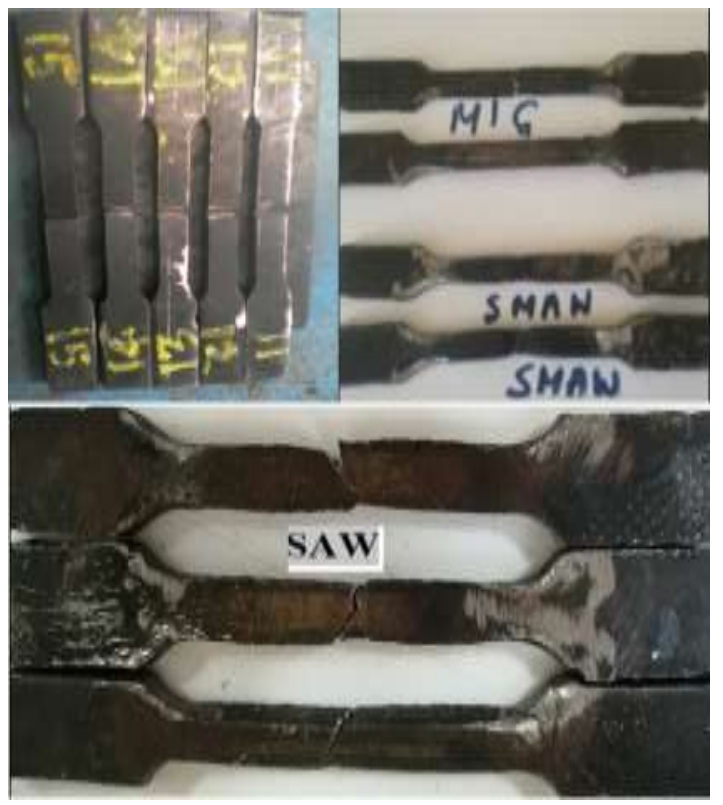

Fig. 11. Tensile tested non-heat treated welded specimen
Table 5: Tensile testing results of non-heat treated welded specimens

\begin{tabular}{|c|c|c|c|c|c|}
\hline $\begin{array}{c}\text { Welding } \\
\text { type }\end{array}$ & $\begin{array}{c}\text { Tensile } \\
\text { strength } \\
\text { in } \\
\mathrm{N} / \mathrm{mm}^{2}\end{array}$ & $\begin{array}{c}\text { Yield } \\
\text { strength } \\
\mathrm{N} / \mathrm{mm}^{2}\end{array}$ & $\begin{array}{c}\text { Modulus } \\
\text { of } \\
\text { elasticity, } \\
\mathrm{GPa}\end{array}$ & $\begin{array}{c}\text { \%age of } \\
\text { elongation }\end{array}$ & $\begin{array}{c}\text { \%age of } \\
\text { reduction } \\
\text { in area }\end{array}$ \\
\hline SAW & 521.7 & 412.4 & 187.8 & 26.934 & 33.06 \\
\hline GMAW & 503.3 & 404.7 & 186 & 20.912 & 29.96 \\
\hline SMAW & 496 & 399 & 186 & 20.514 & 28.17 \\
\hline
\end{tabular}

\subsubsection{Welding Quality Analysis}

All manufacturing processes are imperfect and have an associated non-conformance rate. Manufacturers seeking to achieve higher quality of conformance have a wide range of options to choose from. These can be divided into two categories; improving produced quality of conformance via defect prevention and improving quality of conformance delivered to the customer via inspection. Formula for determination of welding quality index is shown in Table 6 given below. Welding defects were observed are shown in Figure 12 (a) and (b) given below. Quality index of three arcs welding were calculated and given in Table 7 below. Image analysis of weld penetration depth and observed quality defects after penetration are shown in Figure 13 and Figure 14 given below.

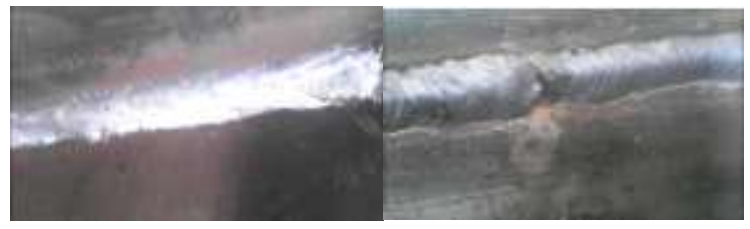

(a)

(b)

Fig. 12.(a) Submerged arc welding $4 \mathrm{~mm}$ diameter preparation (b) Welding defects

Table 6: Formula for determination of welding quality

\begin{tabular}{|c|c|c|}
\hline 1 & Penetration index & $P I=(p / t) \times 100[\%]$ \\
\hline 2 & Convexity index & $\mathrm{CI}=(\mathrm{r} / \mathrm{w}) \times 100[\%]$ \\
\hline 3 & Spattering index & $\mathrm{SI}=(\mathrm{S} / \mathrm{Dr}) \times 100[\%]$ \\
\hline 4 & Spattering rate & $S=\left(F_{\text {elect }}\right.$ or $\left.F_{\text {wire }}\right)-D r$ \\
\hline 5 & Deposition rate & $\operatorname{Dr}=3.6 \times\left(M_{\text {fcp }}-M_{\text {icp }}\right) / \operatorname{tarc}$ \\
\hline 6 & Deposition efficiency & $\begin{array}{c}\mathrm{De}=\operatorname{Dr} /\left(\mathrm{F}_{\text {elect }} \text { or } \mathrm{F}_{\text {wire }}\right) \times 100 \\
{[\%]}\end{array}$ \\
\hline 7 & Electrode feed rate & $f_{\text {elect }}=3.6 \times($ Miel - Mfel $) / \operatorname{tarc}$. \\
\hline 8 & Wire feed rate & $f_{\text {wire }}=60 \times\left(\mathrm{p} \times \emptyset^{2} \times f_{\text {wire }} \times \rho\right) / 4$ \\
\hline
\end{tabular}

Where: $\mathrm{p}=$ the weld penetration $[\mathrm{mm}], \mathrm{t}=$ joint thickness $[\mathrm{mm}], \mathrm{r}=$ bead reinforcement $[\mathrm{mm}], \mathrm{w}=$ bead width $[\mathrm{mm}], \mathrm{S}=$ spattering rate $[\mathrm{kg} / \mathrm{h}], \mathrm{D}_{\mathrm{r}}=$ deposition rate $[\mathrm{kg} / \mathrm{h}], \mathrm{F}_{\text {elect }}=$ covered electrode fusion rate $[\mathrm{kg} / \mathrm{h}]$, $\mathrm{f}_{\text {elect }}=$ wire feed rate $[\mathrm{m} / \mathrm{min}], \mathrm{M}_{\text {iel }}=$ initial mass of the covered electrode, before welding [g], $\mathrm{M}_{\mathrm{fel}}=$ final mass of the covered electrode, after welding [g], $t_{\text {arc }}=\operatorname{arc}$ duration time $[\mathrm{s}], \mathrm{F}_{\text {wire }}=$ wire fusion rate $[\mathrm{kg} / \mathrm{h}], \emptyset=$ wire diameter $[\mathrm{mm}], \mathrm{f}_{\text {wire }}=$ wire feed rate $[\mathrm{m} / \mathrm{min}], \rho=$ 
steel density $\left(7.85 \times 10^{-3} \mathrm{~g} / \mathrm{mm}^{3}\right), M_{\mathrm{fcp}}=$ final mass of the test plate, after welding [g], $\mathrm{M}_{\mathrm{icp}}=$ initial mass of the test plate, before welding [g] and De=deposition efficiency [\%].

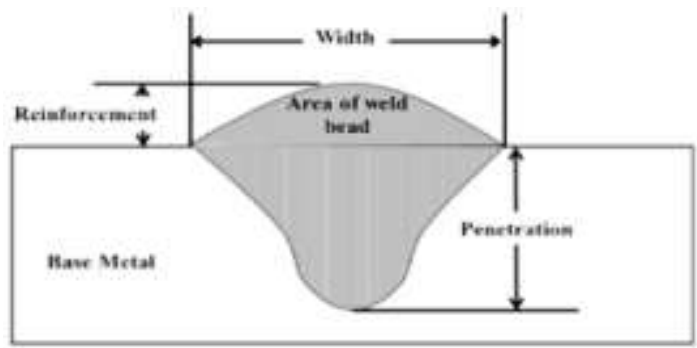

Fig. 13. Image of weld penetration depth

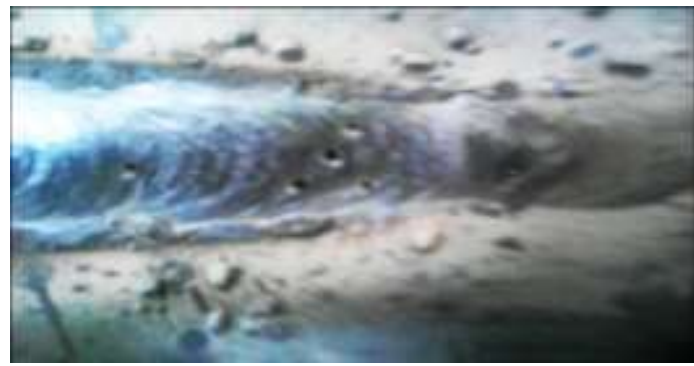

Fig. 14. Images of weld quality defects

\section{Calculation for SAW}

\section{Deposition rate $(\mathrm{Dr})$}

$$
\begin{gathered}
D r=3.6 X(M f c p-M i c p) / \operatorname{tarc} \\
D r=3.6 X \frac{(12.92-12.576)}{5} \\
D r=0.24768
\end{gathered}
$$$$
D r=0.24768 \times 9.15
$$$$
D r=2.266 \mathrm{Kg} / \mathrm{h}
$$

\section{Deposition efficiency (De)}

$$
\begin{gathered}
D e=\left(\frac{D r}{\text { Fwire }}\right) \times 100 \% \\
D e=\left(\frac{2.266}{2.280}\right) \times 100 \% \quad D e=99.38 \%
\end{gathered}
$$

\section{Spattering rate $(S)$}

$$
\begin{gathered}
S=(\text { Fwire })-D r \\
S=(2.280-2.266) \quad S=0.014 \mathrm{Kg} / \mathrm{h}
\end{gathered}
$$

$$
S I=\left(\frac{0.014}{2.266}\right) X 100 \% \quad S I=0.617 \%
$$

\section{Calculation for GMAW}

Deposition rate (Dr)

$$
\begin{gathered}
D r=3.6 X(M f c p-M i c p) / \operatorname{tarc} \\
D r=3.6 X \frac{(12.90-12.576)}{7} \\
D r=0.167
\end{gathered}
$$

$D r=0.167 \times 12.76$

$D r=2.130 \mathrm{Kg} / \mathrm{h}$

\section{Deposition efficiency (De)}

$$
\begin{gathered}
D e=\left(\frac{D r}{\text { Fwire }}\right) \times 100 \% \\
D e=\left(\frac{2.130}{2.165}\right) \times 100 \% \quad D e=98.3 \%
\end{gathered}
$$

Spattering rate $(S)$

$$
S=(F \text { wire })-D r
$$

$$
S=(2.165-2.130) \quad S=0.035 \mathrm{Kg} / \mathrm{h}
$$

Spattering Index (SI)

$$
\begin{gathered}
S I=\left(\frac{S}{D r}\right) \times 100 \% \\
S I=\left(\frac{0.035}{2.130}\right) \times 100 \% \quad S I=1.64 \%
\end{gathered}
$$

\section{Calculation for SMAW}

Deposition rate (Dr)

$$
\begin{gathered}
D r=3.6 X(M f c p-M i c p) / \operatorname{tarc} \\
D r=3.6 X \frac{(12.93-12.576)}{7} \\
D r=0.182
\end{gathered}
$$

$\operatorname{Dr}=0.182 \mathrm{~kg} \mathrm{X} 12.0$

$D r=2.184 \mathrm{Kg} / \mathrm{h}$

Spattering rate $(S)$

$$
S=(\text { Felect })-D r
$$

$$
S=(2.29-2.184) \quad S=0.106 \mathrm{Kg} / \mathrm{h}
$$




\section{Spattering Index (SI)}

$$
\begin{gathered}
S I=\left(\frac{S}{D r}\right) \times 100 \% \\
S I=\left(\frac{0.106}{2.184}\right) \times 100 \% \quad S I=4.853 \%
\end{gathered}
$$

\section{Deposition efficiency (De)}

$$
\begin{gathered}
D e=\left(\frac{D r}{\text { Fwire }}\right) \times 100 \% \\
D e=\left(\frac{2.184}{2.29}\right) \times 100 \% \quad D e=95.371 \%
\end{gathered}
$$

Table 7: Calculated quality index of three arc welding

\begin{tabular}{|c|c|c|c|c|c|c|}
\hline S/No & $\begin{array}{c}\text { Type of } \\
\text { arc } \\
\text { welding }\end{array}$ & $\begin{array}{c}\text { Dr } \\
(\mathrm{Kg} / \mathrm{h})\end{array}$ & $\begin{array}{c}\mathrm{S} \\
(\mathrm{Kg} / \mathrm{h})\end{array}$ & SI \% & De \% & $\begin{array}{c}\mathrm{F}_{\text {wire }} \\
(\mathrm{m} / \mathrm{min})\end{array}$ \\
\hline 1 & SAW & 2.266 & 0.014 & 0.617 & 99.3 & 2.280 \\
\hline 2 & GMAW & 2.130 & 0.035 & 1.64 & 98.3 & 2.165 \\
\hline 3 & SMAW & 2.184 & 0.106 & 4.853 & 95.371 & 2.29 \\
\hline
\end{tabular}

Quality index of three arc welding confirms that SAW is better among them in quality wise.

\subsubsection{Welding Costs Calculation}

Cost analysis is an important tool for product design and material selection. Efficient and effective cost estimation tool is necessary for early design evaluations. Each cost component has been closely analyzed and the major cost components have been included in the cost calculation. In the present case, Costs will be used as a balancing parameter during selection of the most suitable welding process.

The Costs can be based on estimate values (estimations of amount of weld to be deposited) and actual values (amount in fact reached in experimental tests). In this work, the actual deposited amount was used. The reason for that is that the used joint, a butt weld joint with no groove and gap for SAW, makes difficult to estimate the amount of weld to be deposited. It is important to point out that, even in case of grooved joints, each process may deposit different height of reinforcements, misconducting calculations. Therefore, to apply the approach for process selection, weldments of test plates became necessary, simulating real cases. The composition of Costs takes into account materials, electricity, labor and equipment. Indirect Costs will not be considered, since they are approximately the same in terms of comparison. Total welding cost (TWC) is a composition of equipment, materials, and labor and electricity costs. Indirect costs are approximately the same in terms of comparison.
Where: $\mathrm{EC}$ is equipment cost, $\mathrm{MC}$ is material cost, $\mathrm{LC}$ is the labor cost and EPC is the electrical power cost.

Note: all costs are expressed in ETB/m, 1 $\mathrm{ETB}=27.79 \mathrm{USD}$ and material cost comprises the electrode and/ or wire, flux and the gas costs. The investment, depreciation and maintenance costs are the elements of equipment cost. Equations used for determining each term of the costs are represented in Table 8 given below. Specification used for welding

\begin{tabular}{|c|c|c|}
\hline 1 & Material cost(MC) & Cost determining Equations \\
\hline 1.1 & SAW wire (CSw) & $\begin{array}{c}\text { Csw }=\mathrm{P}_{\mathrm{w}} \times(\operatorname{Dr} \times 100 / \text { De }) /\left(\mathrm{t}_{\text {speed }} \mathrm{X}\right. \\
60 / 100)\end{array}$ \\
\hline 1.2 & MIG wire (CMw) & $\begin{array}{c}C m w=P_{w} \times(\operatorname{Dr} \times 100 / \text { De }) /\left(t_{\text {speed }} \times\right. \\
60 / 100)\end{array}$ \\
\hline 1.3 & SMAW electrode (Ce) & $\begin{array}{c}\mathrm{Ce}=\mathrm{P}_{\mathrm{e}} \times(\operatorname{Dr} \times 100 / \mathrm{De}) /\left(\mathrm{t}_{\text {speed }} \mathrm{X}\right. \\
60 / 100)\end{array}$ \\
\hline 1.4 & Flux (Cf) & $\mathrm{Cf}=\mathrm{P}_{\mathrm{f}} \times \mathrm{Rf} \times 100 / \mathrm{t}_{\text {speed }}$ \\
\hline 1.5 & Gas(Cg) & $\mathrm{Cg}=\mathrm{P}_{\mathrm{g} x} \mathrm{R}_{\mathrm{g}} \times 100 / \mathrm{t}_{\text {speed }}$ \\
\hline 2 & Labor cost(LC) & $\mathrm{LC}=\mathrm{S}_{\mathrm{w}} /\left(\mathrm{t}_{\text {speed }} \times 60 / 100 \times \mathrm{f}_{\mathrm{op}} / 100\right)$ \\
\hline 3 & Investment (Ci) & $\begin{array}{c}\mathrm{Ci}=\mathrm{V}_{\mathrm{e}} \times(\mathrm{Ir} / 100) \times \mathrm{D}_{\mathrm{r}} /\left(\mathrm{P}_{\mathrm{m}} \times \mathrm{t}_{\text {speed }} \mathrm{X}\right. \\
60 / 100)\end{array}$ \\
\hline 4 & Depreciation(Cd) & $\mathrm{Cd}=\mathrm{V}_{\mathrm{e}} \times \mathrm{D}_{\mathrm{r}} /\left(\mathrm{T}_{\mathrm{d}} \times \mathrm{P}_{\mathrm{m}} \times \mathrm{t}_{\text {speed }} \times 60 / 100\right)$ \\
\hline 5 & Maintenance $(\mathrm{Cm})$ & $\mathrm{Cm}=\mathrm{E}_{\mathrm{m}} \times \mathrm{Dr} /\left(\mathrm{P}_{\mathrm{m}} \times \mathrm{t}_{\text {speed }} \times 60 / 100\right)$ \\
\hline 6 & Electrical power (EPC) & $\begin{array}{c}\mathrm{EPC}=\left(\operatorname{Im} \times V_{\mathrm{m}} \times \mathrm{P}_{\mathrm{el}}\right) /(1000 \times(\mathrm{ee} / 100) \times \\
\left.\mathrm{t}_{\text {speed }} \times 60 / 100\right)\end{array}$ \\
\hline
\end{tabular}
electrodes is shown in Table 9 given below.

Table 8: Equations used for determining each term of the costs

Where: $\mathbf{P}_{\mathbf{w}}$ is wire price (birr $/ \mathrm{kg}$ ); $\mathbf{P}_{\mathbf{e}}$ is electrode price (birr $/ \mathrm{kg}$ ); $\mathbf{D}_{\mathbf{r}}$ is deposition rate $(\mathrm{kg} / \mathrm{h}) ; \mathbf{D}_{\mathbf{e}}=$ deposition efficiency (\%); $\mathbf{t}_{\text {speed }}$ is travel speed $(\mathrm{cm} / \mathrm{min}) ; \mathbf{P}_{\mathbf{g}}$ is gas price(birr $/ \mathrm{kg}$ ); $\mathbf{P}_{\mathbf{f}}$ is flux price (birr $/ \mathrm{kg}$ ); $\mathbf{R}_{\mathrm{f}}$ is flux flow rate $(\mathrm{kg} / \mathrm{min}) ; \mathbf{R}_{\mathbf{g}}$ is gas flow rate $(1 / \mathrm{min}) ; \boldsymbol{S}_{\mathbf{w}}$ is welder/operator's salary including taxes and duties (birr/h); $\mathbf{f}_{\mathbf{o p}}$ is operating factor (\%); Ve is equipment value(birr); $\quad \mathbf{p}_{\mathbf{m}}$ ismonthly weld production ( $\mathrm{kg} /$ month); $\mathbf{T}_{\mathbf{d}}$ is depreciation time (60 months); $\mathbf{I}_{\mathbf{r}}$ is monthly interest rate; $\mathbf{I}_{\mathbf{m}}$ is welding mean current(A); $\mathbf{V}_{\mathbf{m}}$ is welding mean voltage (v); $\mathbf{P}_{\mathbf{e l}}$ is electricity price

\begin{tabular}{|c|c|c|c|c|c|c|}
\hline$\frac{z}{\infty}$ & 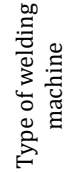 & 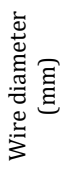 & 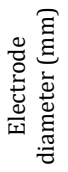 & 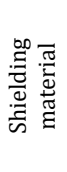 & 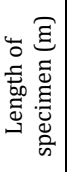 & 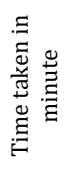 \\
\hline 1 & SAW & 4 & - & Flux & 1 & 9.15 \\
\hline 2 & MIG & 1.2 & - & $\mathrm{CO}_{2}$ & 1 & 12.76 \\
\hline 3 & SMAW & - & 3.2 & - & 1 & 12.00 \\
\hline
\end{tabular}
(birr/kwh); ee is electrical efficiency of the equipment (\%); $\mathbf{E}_{\mathbf{m}}$ is monthly maintenance expense (birr/month).

Table 9: Specification for used welding electrodes

In this case welding steel plates were prepared using plates of plain carbon steel St-52-3, with a dimension of $150 \mathrm{~mm} \times 250 \mathrm{~mm} \times 8 \mathrm{~mm}$ to weld butt welding with $3 \mathrm{~mm}, 2 \mathrm{~mm}$ and no root opening for SMAW,MIG and SAW respectively, welding on the flat position. The welding procedures were as follows: 
Submerged arc welding process (SAW): $4.0 \mathrm{~mm}$ diameter welding wire.

Shield Metal Arc Welding process (SMAW) $3.2 \mathrm{~mm}$ diameter stick electrode.

$\mathrm{CO}_{2}$ Gas Metal arc Welding Process (GMAW): 1.2 $\mathrm{mm}$ diameter welding wire.

\section{SAW welding: Material cost (MC)}

Wire cost (Csw)

$$
\begin{gathered}
C s w=P w X\left(\frac{D r X 100}{d e}\right) /\left(\frac{t_{\text {speed }} \mathrm{X} 60}{100}\right) \\
C s w=415.36 \text { Birr } / \mathrm{Kg} X\left(\frac{2.266 \frac{\mathrm{Kg}}{\mathrm{Hr}} \mathrm{X} 100}{99.38}\right) \\
/\left(\frac{7 \mathrm{~cm} / \mathrm{min} \mathrm{X} 60}{100}\right) \\
C s w=375.80 \mathrm{birr} / \mathrm{meter}
\end{gathered}
$$

Flux cost (Cf)

$$
\begin{aligned}
& C f=\operatorname{PfXRfX100/t_{\text {speed}}} \\
& C f=\frac{\{1.5 \mathrm{birr} / \mathrm{Kg}\} \times 0.21 \times 100}{7 \mathrm{~cm} / \mathrm{min}} \\
& C f=450 \mathrm{birr} / \text { meter }
\end{aligned}
$$

Labor cost (LC)

$$
\begin{gathered}
L C=S w /\left(t_{\text {speed }} X 60 / 100 X \text { fop } / 100\right) \\
L C=45 \mathrm{birr} / \mathrm{hr} /\left(\left(\frac{7 X 60}{100}\right) X(30 / 100)\right) \\
L C=59.52 \mathrm{birr} / \text { meter }
\end{gathered}
$$

Investment $(\mathrm{Ci})$

$$
\begin{gathered}
C i=\operatorname{VeX}\left(\frac{\operatorname{Ir}}{100}\right) X \operatorname{Dr} /\left(P m X t_{\text {speed }} \times 60 / 100\right) \\
C i=99150.03 \operatorname{birr} X\left(\frac{1 \% / \text { month }}{100}\right) X 2.266 \mathrm{~kg} / \mathrm{hr} \\
/(891.56 \mathrm{~kg} / \text { month } X 7 \mathrm{~cm} / \mathrm{minX} 60 \\
/ 100) \\
C i=1
\end{gathered}
$$

Depreciation (Cd)

$$
\begin{aligned}
& C d=\operatorname{VeXDr} /\left(\mathrm{Td} X \mathrm{Pm} X t_{\text {speed }} X 60 / 100\right) \\
& C_{d}=\frac{99150.03 X 2.266 \mathrm{~kg} / 60 \mathrm{~min}}{60 \mathrm{monthX} 891.56 \mathrm{~kg} / \mathrm{month} X 0.07 \mathrm{~cm} / \min X 0.6} \\
& C d=1.67 \mathrm{Birr} / \mathrm{m}
\end{aligned}
$$

\section{GMAW welding: Material cost (MC)}

MIG Wire cost $(\mathrm{Cmw})$

$$
\begin{gathered}
C m w=954.67 \mathrm{birr} / \mathrm{kg} X\left(\frac{2.130 \mathrm{~kg} / \mathrm{hrX} 100}{98.3}\right) \\
/\left(\frac{8.5 \mathrm{~cm} / \mathrm{min} \times 60}{100}\right) \\
C m w=954.67 \times\left(\frac{\mathrm{DrX} 100}{60}\right) /\left(\frac{t_{\text {speed }} \times 60}{100}\right) \\
C m w=676.01 \mathrm{Birr} / \mathrm{meter}
\end{gathered}
$$

$$
\begin{gathered}
C g=P g X \operatorname{Rg} X 100 / t_{\text {speed }} \\
C g=\left(\frac{0.41 \text { Birr }}{\mathrm{kg}}\right) X 1 \mathrm{~kg} / \mathrm{min} X 100 / 0.085 \mathrm{~m} / \mathrm{min} \\
C g=482.35 \mathrm{Birr} / \text { meter }
\end{gathered}
$$

Labor cost (LC)

$$
\begin{gathered}
L C=S w /\left(t_{\text {speed }} X 60 / 100 X f o p / 100\right) \\
L C=45 \mathrm{birr} / \mathrm{h} /\left(\left(8.5 \mathrm{~cm} / \mathrm{min} X\left(\frac{60}{100}\right) X(30 / 100)\right)\right. \\
L C=49.01 \mathrm{Birr} / \text { meter }
\end{gathered}
$$

Investment $(\mathrm{Ci})$

$$
\begin{gathered}
C i=\operatorname{VeX}\left(\frac{\operatorname{Ir}}{100}\right) X \operatorname{Dr} /\left(P m X t_{\text {speed }} \times 60 / 100\right) \\
C i=99150.03 \operatorname{birr} X\left(\frac{1 \% / m o n t h}{100}\right) X 2.130 \mathrm{~kg} / \mathrm{hr} \\
/(690.156 \mathrm{~kg} \\
/ \text { month } X 8.5 \mathrm{~cm} / \mathrm{min} \times 60 / 100) \\
C i=1
\end{gathered}
$$

Depreciation (Cd)

$$
\left.C d=V e X \frac{D r}{\left(T d X P m X t_{\text {speed }} X 60 / 100\right.}\right)
$$

$=99150.03 \mathrm{birr} X 2.130 \mathrm{~kg} / \mathrm{hr}$

/60monthX690.156 kg/month X $0.085 \mathrm{~m} / \mathrm{min} X 60 / 100$ )

Cd $=1.67 \mathrm{Birr} / \mathrm{m}$

\section{SMAW welding: Material cost (MC)}

Electrode cost (Ce)

$$
\begin{gathered}
C e=\operatorname{PeX}\left(\frac{\operatorname{Dr} X 100}{d e}\right) /\left(\frac{t_{\text {speed }} \times 60}{100}\right) \\
C e=256.26 \mathrm{Birr} / \mathrm{kg} X\left(\frac{2.184 \mathrm{~kg} / \mathrm{hr} X 100}{95.371}\right) \\
/\left(\frac{6 \mathrm{~cm} / \mathrm{min} \times 60}{100}\right) \\
C e=271.68 \mathrm{Birr} / \mathrm{m}
\end{gathered}
$$

Labor cost (LC)

$$
\begin{gathered}
L C=S w /\left(t_{\text {speed }} X 60 X 100 X \text { fop } / 100\right) \\
L C=45 \mathrm{Birr} / \mathrm{hr} /\left(\left(0.06 \mathrm{~m} / \mathrm{min} X\left(\frac{60}{100}\right) X(65 / 100)\right)\right. \\
L C=32.05 \mathrm{Birr} / \mathrm{meter}
\end{gathered}
$$

Investment $(\mathrm{Ci})$

$$
\begin{gathered}
C i=\operatorname{VeX}\left(\frac{\operatorname{Ir}}{100}\right) X \operatorname{Dr} /\left(P m X t_{\text {speed }} \times 60 / 100\right) \\
C i=99150.03 \operatorname{birr} X\left(\frac{1 \% / m o n t h}{100}\right) X 2.184 \frac{\mathrm{kg}}{\mathrm{hr}} \\
/\left(950.5 \frac{\mathrm{kg}}{\text { month }} \times 0.06 \mathrm{~m} / \mathrm{min} \times 60\right. \\
/ 100)
\end{gathered}
$$


Depreciation (Cd)

$$
\left.C d=V e X \frac{D r}{\left(T d X P m X t_{\text {speed }} X\right.} 60 / 100\right)
$$

$=99150.03 \operatorname{Birr} X 2.184 \mathrm{~kg} / \mathrm{hr}$

/60months X950.5 kg/monthX $0.06 \mathrm{~m} / \mathrm{min} X 60 / 100$ )

$$
C d=1.7578 \mathrm{Birr} / \text { meter }
$$

\section{SAW (Labor cost, Electrode cost and Electric power Cost)}

$\frac{\text { Laborcost }}{\text { meter of weld }}$
$=\left[\frac{\frac{\text { Labor and Overhead Costs }}{\text { Hour }} X \frac{\text { Kilograms of weld deposite }}{\text { meter of weld }}}{\text { Deposition Rate X Operating Factor }}\right]$ $\frac{\text { Labor cost }}{\text { meter of weld }}=\left[\frac{\frac{(55 \times 5) \text { birr }}{\text { Hour }} \times \frac{0.325 \mathrm{KG}}{\text { meterofweld }}}{2.266 \times 0.6}\right]$ $\frac{\text { Labor cost }}{\text { meter of weld }}=\left[\frac{\frac{275 \text { birr }}{\text { Hour }} X \frac{0.325 \mathrm{KG}}{\text { meterofweld }}}{2.266 \mathrm{Kg} / \mathrm{hr} \times 0.6}\right]$

$$
\frac{\text { Laborcost }}{\text { meterofweld }}=65.736 \mathrm{Birr}
$$

wire cost

$\overline{\text { meter of weld }}$

$=\left[\frac{\frac{\text { Kilograms of weld deposite }}{\text { meter of weld }} X \frac{\text { Cost of electrode }}{\text { Kilogram }}}{\text { Deposition Ef ficiency }}\right]$

$\frac{\text { wire cost }}{\text { meter of } \text { weld }}=\left[\frac{\frac{0.325 \mathrm{KG}}{\text { meterof weld }} X \frac{53.35}{\text { Kilogram }}}{0.993}\right]$

$$
\frac{\text { wire cost }}{\text { meter of weld }}=17.460 \text { Birr }
$$

Electric power cost

meter of weld

Welding Current X Welding Voltage

$=\frac{\text { Power source efficiency }}{\text { Electricpowercost }}$

$\frac{\text { Electricpowercost }}{\text { meter of weld }}=\frac{250 \times 28}{50} \times 0.0035 \times 9.15$

$$
\frac{\text { Electric power cost }}{\text { meter of weld }}=4.4835 \text { birr }
$$

\section{GMAW (Labor cost, Electrode cost and Electric power Cost)}

$$
\begin{gathered}
{\left[\frac{\frac{\text { Labor and Overhead Costs }}{\text { Hour }} X \frac{\text { Kilograms of weld deposite }}{\text { meter of weld }}}{\text { DepositionRateXOperatingFactor }}\right.} \\
\frac{\text { Labor cost }}{\text { meter of weld }}=\left[\frac{\frac{(55 \times 5) \text { birr }}{\text { Hour }} X \frac{0.325 \mathrm{KG}}{\text { meterofweld }}}{2.130 \mathrm{Kg} / \mathrm{hr} \text { X } 0.6}\right]
\end{gathered}
$$

$$
\begin{gathered}
\frac{\text { Labor cost }}{\text { meter of weld }}=\left[\frac{\frac{275 \text { birr }}{\text { Hour }} X \frac{0.325 \mathrm{KG}}{\text { meterofweld }}}{2.130 \times 0.6}\right] \\
\frac{\text { Labor cost }}{\text { meter of weld }}=69.933 \text { Birr }
\end{gathered}
$$$$
\begin{aligned}
& \frac{\text { wire cost }}{\text { meter of weld }} \\
& =\left[\frac{\frac{\text { Kilograms of weld deposite }}{\text { meter of weld }} \times \frac{\text { Cost of electrode }}{\text { Kilogram }}}{\text { Deposition Efficiency }}\right]
\end{aligned}
$$$$
\frac{\text { wire cost }}{\text { meter of } \text { weld }}=\left[\frac{\frac{0.325 \mathrm{KG}}{\text { meterofweld }} X \frac{63.65}{\text { Kilogram }}}{0.983}\right]
$$

$$
\frac{\text { wirecost }}{\text { meterof } w e l d}=21.043 \mathrm{Birr}
$$

$$
\begin{aligned}
& \frac{\text { Electric power cost }}{\text { meter of weld }} \\
& =\frac{\text { Welding Current X Welding Voltage }}{\text { Power source efficiency }} X \text { power cost X welding t } \\
& \quad \frac{\text { Electric power cost }}{\text { meter of weld }}=\frac{185 X 23}{50} \times 0.0035 \times 12.76 \\
& \quad \frac{\text { Electric power cost }}{\text { meter of weld }}=3.80 \mathrm{birr}
\end{aligned}
$$

\section{SMAW (Labor cost, Electrode cost and Electric power Cost)}

$$
\begin{aligned}
& \text { Labor cost } \\
& \overline{\text { meter of weld }} \\
& =\left[\frac{\frac{\text { LaborandOverheadCosts }}{\text { Hour }} X \frac{\text { Kilogramsofwelddeposite }}{\text { meterofweld }}}{\text { Deposition Rate X Operating Factor }}\right] \\
& \frac{\text { Labor cost }}{\text { meter of weld }}=\left[\frac{\frac{(55 \times 5) \text { birr }}{\text { Hour }} X \frac{0.325 \mathrm{KG}}{\text { meter of weld }}}{2.184 \times 0.35}\right] \\
& \frac{\text { time }}{\text { meter of } \text { weld }}=\left[\frac{\frac{275 \text { birr }}{\text { Hour }} X \frac{0.325 \mathrm{KG}}{\text { meterofweld }}}{2.184 \mathrm{Kg} / \mathrm{hrX} 0.35}\right] \\
& \frac{\text { Laborcost }}{\text { meterofweld }}=116.92 \mathrm{Birr}
\end{aligned}
$$

Electrode cost

meter of weld

$$
=\left[\frac{\frac{\text { Kilograms of weld deposite }}{\text { meter of weld }} X \frac{\text { Cost of electrode }}{\text { Kilogram }}}{\text { Deposition Efficiency }}\right]
$$

$$
\begin{aligned}
& \frac{\text { Electrode cost }}{\text { meter of weld }}=\left[\frac{\frac{0.325 \mathrm{KG}}{\text { meter of } \text { weld }} \times \frac{156.26}{\text { Kilogram }}}{0.95371}\right] \\
& \frac{\text { Electrode cost }}{\text { meter of weld }}=53.249 \mathrm{Birr}
\end{aligned}
$$




\section{Electric power cost}

meter of weld

$=\frac{\text { Welding Current } X \text { Welding Voltage }}{\text { Power source efficiency }} X$ power cost $X$ welding time

$$
\begin{aligned}
& \frac{\text { Electric power cost }}{\text { meter of weld }}=\frac{90 \times 25}{50} \times 0.0035 \times 12.0 \\
& \frac{\text { Electric power cost }}{\text { meter of weld }}=1.89 \mathrm{Birr}
\end{aligned}
$$

Table 10: Total cost/m for three different electrode diameters in respect of deposition rate, operating factor, labor cost, depreciation, power efficiency etc.

\begin{tabular}{|c|c|c|c|}
\hline Electrode/wire type & $\begin{array}{c}\text { H08MnA } \\
\text { SAW wire } \\
\text { dia. } 4 \mathrm{~mm}\end{array}$ & $\begin{array}{c}\text { ER70S-6 } \\
\text { copper } \\
\text { wire dia. } \\
1.2 \mathrm{~mm}\end{array}$ & $\begin{array}{c}\text { E7018 } \\
\text { Dia. } \\
3.2 \mathrm{~mm}\end{array}$ \\
\hline $\begin{array}{c}\text { Weight of deposit per meter } \\
\text { (Kg/m) }\end{array}$ & 0.325 & 0.325 & 0.325 \\
\hline Deposition efficiency (\%) & 99.3 & 98.3 & 95.371 \\
\hline Deposition rate (Kg/hr) & 2.266 & 2.130 & 2.184 \\
\hline Welding current (amps) & 250 & 185 & 90 \\
\hline Welding voltage (volts) & 28 & 23 & 25 \\
\hline Operating factor (\%) & 60 & 60 & 35 \\
\hline Labor + Overhead cost (ETB/hr) & 55 & 55 & 55 \\
\hline $\begin{array}{c}\text { Electrode cost per Kilogram } \\
\text { (ETB/Kg) }\end{array}$ & 53.35 & 63.65 & 156.26 \\
\hline Power source efficiency (\%) & 50 & 50 & 50 \\
\hline Depreciation(C) [ETB/m] & 1.67 & 1.67 & 1.7578 \\
\hline $\begin{array}{c}\text { Labor + Overhead Cost/meter of } \\
\text { weld (ETB/m) }\end{array}$ & 65.736 & 69.933 & 116.92 \\
\hline $\begin{array}{c}\text { Electrode cost/ Meter of weld } \\
\text { (ETB/m) }\end{array}$ & 17.640 & 21.065 & 53.249 \\
\hline $\begin{array}{c}\text { Electric power cost/Meter of } \\
\text { weld (ETB/m) }\end{array}$ & 4.4835 & 3.80 & 1.89 \\
\hline Total [ETB/m) & 87.8592 & 94.798 & 172.059 \\
\hline
\end{tabular}

Total cost/m for three different electrode diameters in respect of welding time, deposition rate, operating factor, labor cost, power efficiency etc. are shown in Table 10 given above. Welding time, deposition rate, deposition efficiency, welding current, welding voltage, operating factor and power source efficiency observed data are presented in Table 11 given below. Results of man power, material, electrical and total costs(Birr $/ \mathrm{m})$ are presented in Table 12 given below. Comparison of welding parameters and cost are shown in Figure 15 given below. Comparison of welding consumables and cost are shown separately in Figure 16 given below.

Table 11: Welding time, deposition rate, deposition efficiency, welding current, welding voltage, operating factor and power source efficiency required values for three welding process

\begin{tabular}{|c|c|c|c|}
\hline Process type & SAW & GMAW & SMAW \\
\hline Welding time (min) & 9.15 & 12.76 & 12.0 \\
\hline $\begin{array}{c}\text { Weight of deposit per } \\
\text { meter (Kg/m) }\end{array}$ & 0.325 & 0.325 & 0.325 \\
\hline Deposition efficiency (\%) & 99.3 & 98.3 & 95.371 \\
\hline Deposition rate (Kg/hr) & 2.266 & 2.130 & 2.184 \\
\hline Welding current (amps) & 250 & 185 & 90 \\
\hline Welding voltage (volts) & 28 & 23 & 25 \\
\hline Operating factor (\%) & 60 & 60 & 35 \\
\hline $\begin{array}{c}\text { Power source efficiency } \\
(\%)\end{array}$ & 50 & 50 & 50 \\
\hline
\end{tabular}

Table 12: Results of man power, material, electrical and total costs-(Birr $/ \mathrm{m})$

\begin{tabular}{|c|c|c|c|}
\hline Process type & SAW & GMAW & SMAW \\
\hline $\begin{array}{c}\text { Labor + Overhead cost } \\
\text { (Birr/hr) }\end{array}$ & 55 & 55 & 55 \\
\hline $\begin{array}{c}\text { Electrode cost per Kilogram } \\
\text { (Birr/Kg) }\end{array}$ & 53.35 & 63.65 & 156.26 \\
\hline $\begin{array}{c}\text { Electric power cost per } \\
\text { kilowatt (Birr/Kw-hr) }\end{array}$ & 0.4993 & 0.4993 & 0.4993 \\
\hline $\begin{array}{c}\text { Labor + Overhead } \\
\text { Cost/meter of weld (Birr/m) }\end{array}$ & 65.736 & 69.933 & 116.92 \\
\hline $\begin{array}{c}\text { Electrode + consumable } \\
\text { cost/ meter of weld } \\
\text { (Birr/m) }\end{array}$ & 41.57 & 45.5 & 52.5 \\
\hline $\begin{array}{c}\text { Electric power cost/meter of } \\
\text { weld (Birr/m) }\end{array}$ & 4.4835 & 3.80 & 1.89 \\
\hline Total (Birr/m) & 220.6388 & 238.3823 & 383.0693 \\
\hline
\end{tabular}

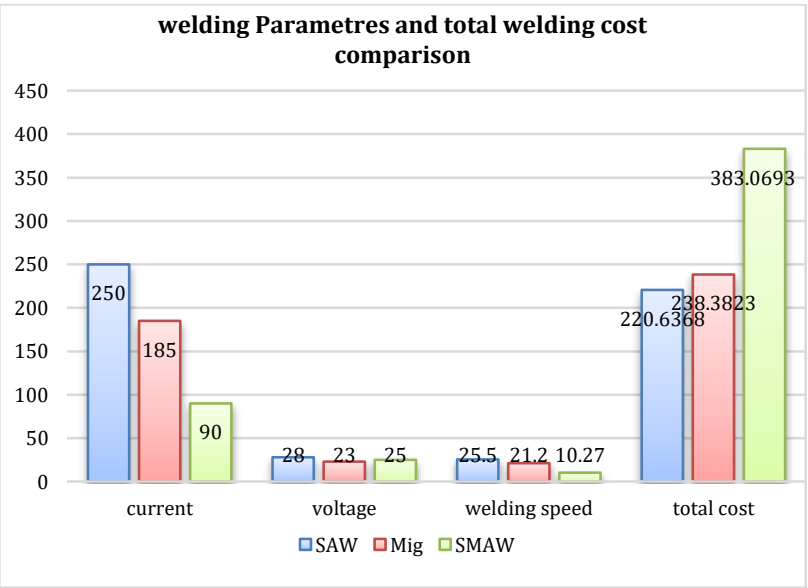

Fig. 15.Comparison of welding parameters and cost

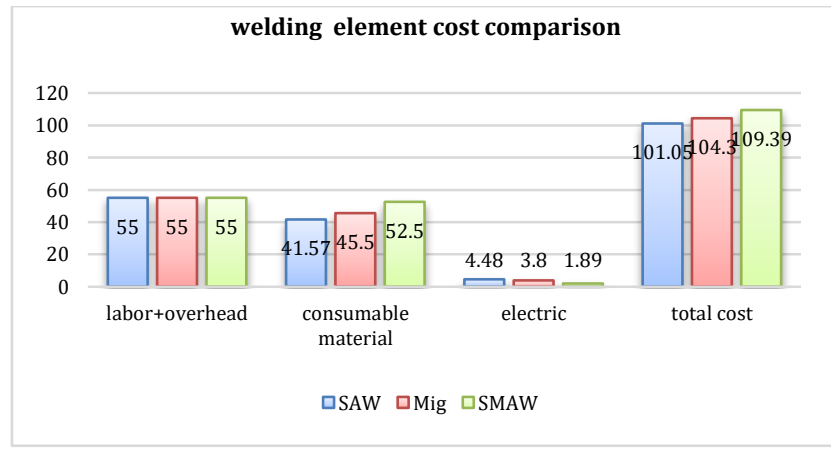

Fig. 16.Comparison of welding consumables and cost

\subsection{Discussion}

As a result, from the quality and cost analysis of the samples taken, the product was directed to be expensive because of the material, labor and electricity. To achieve the mechanical property and cost target of welding was trail analysis was done by experimentation the three welding on St- 52-3 plate with material thickness of $8 \mathrm{~mm}$.

By analyzing data, it can be discussed for the SAW to be selective in term of saving welding time, high deposition efficiency, and by deposition rate. However, 
in respect of welding current, welding voltage, and eclectic power cost per weld meter SAW has slight than GMAW.

It is possible to reduce total welding cost of fabrications by judicious choice of all the factors that goes into the cost and simultaneously achieve improved assured quality as specifically required for the application.

\section{Conclusion}

The objective of this work is to analyses how to select the best arc welding process of the products based on quality and low welding cost. Based on the best performance of quality and cost analyses, it is possible to conclude that:

The selection of the best welding process is possible to a certain industrial activity, considering the performance of quality and costs, according to market requirements of the company.

Radiographic test results and Visual inspection examined welded joint indicates that SAW have possess better quality among three arc weld process. However, fewer defects are attendant in all of them. Mechanical test results in non-treated condition confirm the SAW is chosen better in comparison to the GMAW and SMAW.

Analysis by quality index of three arc welding confirms that SAW is better among them in quality.

It is possible to achieve required consistent quality welding for an application with adaptability to advanced applications with simultaneous reduction in overall cost by using SAW process. It is also possible to save cost by adopting total quality concept in using other processes like GMAW also compared to other arc process.

Overall, SAW is selective among them for quality wise. However, cost incurs little high for GMAW.

\section{Acknowledgements}

We would like to express our thanks to department of Mechanical Engineering, Solid Mechanics Chair and Mesfin Industrial Engineering for allowing us to use their laboratory.

\section{References}

An American National Standard AWS B4.0 (May 2, 2007), Standard Methods for Mechanical Testing of Welds, 7th Edition, Supersedes ANSI/AWSB4.0-98.

AWS D1.1/D1.1M (July 2, 2008),An American National Standard, Structural welding code-steel, 21st Edition, under the direction of the AWS technical committee.

Ajit. H,Ashwani. D, and Satpal. S(October 2012), Optimization of MIG welding process parameter to predict maximum yield strength in AISI 1040, International journal of Mechanical engineering and Robotics research, 1( 3),203213.

Designation of E190- 92(2008),Standard Test Method for Guided Bend Test for Ductility of Welds, ASTM, international.(Reapproved).

Patel C. N. and ChaudharyS.(2013), Parametric Optimization of Weld Strength of MetalInert Gas Welding and Tungsten Inert Gas Welding by using Analysis of Variance and Grey Relational Analysis, International Journal of Research in Modern Engineering and Emerging Technology, 1(3).

Lakshminarayanan A.K., Balasubramanian V. and Elangovan K.(2009), Effect of welding processes on tensile properties of AA6061 Aluminium alloy joints,International Journal of Advanced Manufacturing Technology, 40,286-296.

Chaudhuri S., Welding Cost, Economics- GMAW \& MMAW Process\& Quality, Indian Institute of Welding lecture tutorial.

KumarS., and Nand S. (January2011),Estimation and Comparison of Welding Cost of MIG \& MAG Process on Mild Steel, Proceedings of the National Conference on Recent Advances In Manufacturing Engineering \& Technology, 10-11.

TipajiP.K., AlladaV., and MistraR.(2007), A Cost Model For The Metal Inert Gas (Mig) Welding PROCESS, Proceedings of the ASME 2007 International Design Engineering Technical Conferences \& Computers and Information in Engineering Conference IDETC/CIE 2007 September, 4-7, Las Vegas, Nevada, USA.

TewariS. P., Gupta AnkurandJyotiPrakash(2010) ,effect of welding parameters on the weldability of material, International Journal of Engineering Science and Technology, 2(4), 512-516.

Designation E8/E8M-13a,Standard Test Methods for Tension Testing of MetallicMaterials1, ASTM, international, American Association State Highway and Transportation Officials Standard, AASHTO No. T68, an American National Standard.

Pradip D. Chaudhari and NitinN.More (2014), Effect of welding process parameters on tensile strength, IOSR journal of engineering, 04(05),01-05.

Gupta J.K. and Khurmi R.S,(2005), A text book of machine design (multicolor) Eurasian, publishing house (Pvt Ltd) ram Nagra New Delhi India. 